\title{
PENGARUH TINGKAT PENGETAHUAN, KUALITAS LAYANAN, DAN TINGKAT LITERASI KEUANGAN SYARIAH TERHADAP PENGAMBILAN KEPUTUSAN MASYARAKAT MUSLIM MENGGUNAKAN PRODUK PERBANKAN SYARIAH DI DAERAH ISTIMEWA YOGYAKARTA
}

\author{
Rahmawati Deylla Handida \& Maimun Sholeh \\ Universitas Negeri Yogyakarta, Indonesia \\ delagregian@yahoo.co.id,maimunsholeh@uny.ac.id
}

\begin{abstract}
Abstrak: Penelitian ini bertujuan untuk mengetahui pengaruh Tingkat Pengetahuan, Kualitas Layanan, dan Tingkat Literasi Keuangan Syariah baik secara parsial maupun simultan terhadap Pengambilan Keputusan Masyarakat Muslim Menggunakan Produk Perbankan Syariah di Daerah Istimewa Yogyakarta. Penelitian ini merupakan jenis penelitian kuantitatif dengan pendekatan asosiatif kausal. Populasi dalam penelitian ini adalah masyarakat muslim yang menggunakan produk perbankan syariah di DIY. Sampel penelitian berjumlah 100 masyarakat muslim dengan menggunakan metode purposive sampling. Teknik pengumpulan data yang digunakan adalah kuesioner. Teknik analisis data yang digunakan yaitu analisis regresi linear ganda. Hasil penelitian menunjukkan bahwa tingkat pengetahuan, kualitas layanan, dan tingkat literasi keuangan syariah berpengaruh positif dan signifikan terhadap keputusan masyarakat muslim menggunakan produk perbankan syariah di DIY baik secara parsial maupun simultan.
\end{abstract}

Kata kunci: Tingkat Pengetahuan, Kualitas Layanan, Tingkat Literasi Keuangan Syariah, Produk Perbankan Syariah

\section{THE IMPACT OF KNOWLEDGE LEVEL, SERVICE QUALITY, AND ISLAMIC FINANCIAL LITERACY LEVEL TOWARD MUSLIM COMMUNITY TO USE SYARIAH BANKING PRODUCT IN DAERAH ISTIMEWA YOGYAKARTA}

\begin{abstract}
This research aims to know the impact of knowledge level, service quality, and Islamic financial literacy level partially and stimultancously toward taking decision muslim community to use syariah banking product in Daerah Istimewa Yogyakarta (DIY). This study was classified into quantitative research with a causal associative approach. The research population comprised muslim community who used syariah banking product in DIY. The sample of this study was a hundred muslim community, was selected by using purposive sampling technique. The data was collected by using questionnaire. The data was analyzed by using multiple linear regression analysis. The result of the study shows that the knowledge level, the service quality, and the Islamic financial literacy have significant effects towards taking decision muslm community to use syariah banking product in DIY partially and silmutanously.
\end{abstract}

Keywords: Knowledge Level, Service Quality, Islamic Financial Literacy, Syariah Banking Product.

\section{PENDAHULUAN}

Perbankan syariah mengalami perkembangan yang cukup pesat jika dilihat sejak awal mulai masuknya sistem ekonomi Islam ke Indonesia. Keberadaan perbankan syariah mulai diakui dengan ditandai munculnya UU. NO. 7/1992 tentang perbankan yang juga telah diubah ke dalam UU. No. 8/1998; di mana ditegaskan bahwa sistem perbankan syariah ditempatkan sebagai bagian dari sistem perbankan nasional, kemudian juga tertuang dalam UU. No. 10/1998 yang mengatur landasan hukum dan jenis-jenis usaha yang dioperasikan oleh Bank Syariah. Melalui UU ini terdapat aturan yang menyarankan agar Bank Konvensional yang ada di Indonesia untuk membuat cabang Syariah atau mengkonversi diri menjadi Bank Syariah serta semua ketentuan pelaksanaan baik berupa peraturan pemerintah, keputusan Menteri Keuangan maupun surat Bank Indonesia. 
Dari awal terbentuk hingga saat ini perbankan syariah terus mengalami perkembangan yang cukup baik jika dilihat dari total asset tahun 2015, 2016, dan 2017 terus mengalami peningkatan. Untuk Bank Umum Syariah mulai dari tahun 2015 hingga 2018 mengalami peningkatan walaupun di bulan Januari 2018 mengalami sedikit penurunan namun masih ada kemungkinan terdapat kenaikan di akhir tahun 2018 mendatang.

Kenaikan-kenaikan tersebut tidak terlepas dari semakin meningkatnya minat masyarakat untuk mengambil produk bank syariah karena mayoritas masyarakat Indonesia adalah muslim. Namun menurut Agustianto, selaku ketua DPP Ikatan Ahli Ekonomi Islam Indonesia (IAEI), memaparkan bahwa sharing market yang dihasilkan oleh bank syariah di Indonesia masih terbilang sangat kecil. Market Share masih di bawah 4\% dari total aset bank secara nasional. Jika dilihat dari hasil penelitian yang dilakukan oleh Bank Indonesia yang diambil dari buku Panduan Investasi Perbankan Syariah (2007: 11) menerangkan bahwa kurang lebih sepertiga dari wilayah kabupaten atau kotamadia di Indonesia menunjukkan sekitar $42 \%$ wilayah berkategori cukup potensial sampai dengan potensial untuk perbankan syariah. Seperti halnya dengan yang diungkapkan oleh Agustianto bahwa jumlah umat muslim potensial untuk menjadi customer bank syariah yaitu lebih dari 100 juta orang.

Jika berbicara mengenai daerah yang cukup potensial hingga potensial untuk perkembangan perbankan syariah, berdasarkan hasil proyeksi Penduduk Provinsi Daerah Istimewa Yogyakarta (DIY) 2010-2017, besarnya penduduk DIY tahun 2017 mencapai 3.762.167 jiwa, dengan persentase jumlah penduduk laki-laki 49,46 persen, dan penduduk perempuan 50,54 persen. Berdasarkan data yang diambil dari publikasi Otoritas Jasa Keuangan (OJK) DIY, per akhir tahun 2015, posisi aset perbankan syariah di Yogyakarta mencapai nilai Rp4,8 triliun. Sedangkan jumlah DPK mencapai Rp3,9 triliun dan penyaluran pembiayaan sebesar Rp3,1 triliun. Angka tersebut mengalami pertumbuhan yaitu sebesar $8 \%$, dapat terbilang lebih tinggi hampir dua kali lipat dibandingkan ratarata nasional yang baru mencapai 4,5\% (jogja.tribunnews.com, 2016). Jumlah bank syariah di DIY sebanyak 60 bank. Perinciannya adalah 47 bank umum syariah (BUS) dan 13 unit usaha syariah (UUS).

Perkembangan aset dan jumlah kantor yang cukup pesat merupakan kemajuan yang baik terhadap popularitas Perbankan Syariah di DIY. Namun menurut Dhani Gunawan selaku Direktur Perbankan Syariah OJK mengungkapkan bahwa terdapat beberapa masalah yang menjadi tantangan dan perlu diatasi oleh perbankan syariah. Pertama, pemahaman dan tingkat melek ilmu bank syariah masih rendah. Kedua, bank syariah masih memiliki produk yang cenderung kurang variatif dan menjadi pilihan sulit bagi masyarakat serta belum memiliki kemudahan melalui teknologi perkembangan zaman. Akses perbankan syariah masih kurang pada sektor-sektor tertentu, khususnya infrastruktur. Ketiga, perlunya peningkatan pengawasan pada pengelolaan dana bank syariah. Selain ketiga masalah tersebut masih ada masalah permodalan, kualitas sumber daya manusia, dan lain-lain.

Secara umum dalam menentukan keputusannya dalam memilih sebuah produk, nasabah memiliki kualifikasi tersendiri. Khususnya pada keputusan dalam memilih produk perbankan, biasanya calon nasabah akan tertarik pada produk bank yang memberikan banyak keuntungan dan manfaat bagi dirinya. Mayarakat yang memiliki banyak informasi mengenai bank syariah dan produk yang mengikutinya akan cenderung lebih mudah dalam menentukan pilihannya. Apabila konsumen mempunyai tingkat pengetahuan yang lebih tinggi, maka konsumen tersebut dapat lebih baik dalam mengambil keputusan. Masyarakat akan lebih bijaksana dalam mengolah informasi yang didapatkan. Semakin banyak pengetahuan tentang bank syariah yang dimiliki konsumen, semakin tinggi pula kemungkinan untuk berhubungan dengan bank syariah. Sehingga faktor yang 
paling mendasar pada pengembangan bank syariah adalah pengetahuan nasabah. Pengertian pengetahuan sendiri dapat dikatakan pengalaman nyata yang tersimpan di dalam pikiran manusia secara konkret. Sumber pengetahuan dapat diperoleh melalui berbagai media, baik media cetak maupun media elektronik.

Penelitian yang dilakukan oleh Echchabi dan Aziz (2012) dalam jurnal penelitian yang dilakukan oleh Kuat Ismanto (2018) menerangkan bahwa alasan tidak minat responden terhadap bank syariah lebih didasarkan pada fasilitas dan produk bank syariah yang kurang menarik. Kecocokan keuntungan pribadi memiliki pengaruh signifikan terhadap keputusan menggunakan bank syariah di Negara Maroko. Di sisi lain, mereka masih setia terhadap layanan bank konvensional karena ada beberapa layanan yang belum bisa disediakan oleh bank syariah.

Selain dari pengetahuan konsumen dan kualitas pelayanan, literasi keuangan juga penting dalam mempengaruhi keputusan masyarakat untuk menggunakan produk perbankan syariah atau tidak. Literasi keuangan menjadi penting dalam kaitannya dengan perbankan syariah dan produk pengikutnya karena dalam beberapa riset yang telah dilakukan sebelumnya menerangkan, dengan tingginya tingkat literasi keuangan akan memacu pertumbuhan perekonomian suatu negara. Masyarakat yang memiliki pemahaman mengenai keuangan dengan segala aspeknya tentu dapat dengan mudah meningkatkan kesejahteraan hidupnya dan dengan demikian dapat pula meningkatkan pertumbuhan ekonomi suatu daerah hingga negara. Literasi keuangan sendiri memiliki pengertian mengenai bagaimana cara berpikir seseorang terhadap kondisi keuangannya sehingga mengerti mengenai bagaimana mengambil keputusan dalam pengelolaan keuangan sehingga menjadi lebih baik lagi. Menurut sejumlah penelitian yang telah dilakukan menunjukkan bahwa tingkat literasi keuangan syariah yang dimiliki oleh masyarakat Indonesia masih tergolong rendah. Sebagian masyarakat dengan ekonomi menengah ke bawah tidak berhubungan langsung terhadap layanan keuangan. Di Indonesia sendiri menurut data yang dihasilkan oleh bank dunia menerangkan bahwa hanya sebesar 52\% dari masyarakat yang bersinggungan dengan layanan keuangan formal, sebesar 31\% masyarakat mengakses keuangan informal. Hal menyayangkan lainnya sebanyak 50\% dari masyarakat Indonesia diperkirakan tidak mengerti tentang jasa dan produk keuangan baik informal maupun formal.

\section{METODE}

Penelitian ini merupakan penelitian kuantitatif dengan pendekatan asosiatif kausal. Menurut Sugiyono (2015) penelitian asosiatif adalah penelitian yang bermaksud untuk mengetahui hubungan sebab akibat antar variabel yaitu dua variabel atau lebih. Pada penelitian asosiatif kausal adalah penelitian yang ingin melihat hubungan sebab akibat antara variabel bebas dengan variabel terikat. Penelitian di laksanakan di DIY pada bulan Oktober 2018.

Populasi penelitian ini adalah masyarakat muslim di DIY yang menggunakan produk perbankan syariah di mana tidak diketahui jumlahnya secara pasti. Peneliti mengambil sampel dari populasi tersebut sejumlah 100 berdasarkan rumus Stanley Lemeshow. Teknik pengumpulan data yang digunakan dalam penelitian ini adalah menggunakan teknik kuesioner. Kuesioner adalah sebuah teknik penelitian yang digunakan untuk mengumpulkan data dengan cara memberi seperangkat pertanyaan atau pernyataan kepada responden untuk dijawab (Sugiyono, 2015). Pengukuran variabel menggunakan skala Likert dengan empat alternatif jawaban. Pengukuran validitas dan reliabilitas instrumen diujikan pada 30 masyarakat muslim yang menggunakan produk perbankan syariah. Teknik analisis data menggunakan analisis deskriptif variabel, uji asumsi klasik meliputi uji normalitas, uji multikolinearitas, dan uji heterosedastisitas. Pengajuan hipotesis menggunakan persamaan regresi linear berganda (Ali Muhson, 2017). 


\section{HASIL DAN PEMBAHASAN}

Pertama dilakukan terlebih dahulu uji asumsi klasik sebagai prasyarat dapat dilakukannya uji hipotesis yang meliputi uji normalitas, multikolinearitas, dan heterosedastisitas. Hasil dari uji normalitas menunjukkan bahwa keempat variabel berdistribusi normal. Ditunjukkan dengan nilai Asymp Sig yang lebih dari 0,05. Dengan terpenuhinya prasyarat normalitas, maka analisis selanjutnya bisa dilakukan dengan statistik parametrik. Hasil dari uji multikolinearitas menunjukan bahwa diperoleh nilai VIF masing-masing variabel sebesar 1,127; 1,093; dan 1,033. Dapat ditarik kesimpulan bahwa tidak terjadi multikolinearitas pada hubungan variabel tingkat pengetahuan, kualitas layanan, dan tingkat literasi keuangan syariah.

Uji Heterosedastisitas dilakukan guna mengetahui homogenitas varians eror untuk setiap kali nilai variabel bebasnya. Uji heterosedastisitas dilakukan menggunakan uji Park. Hasil uji heterosedastisitas menunjukkan bahwa analisis regresi tersebut memenuhi syarat heterosedastisitas ditunjukkan dengan nilai sig sebesar 0,466 (lebih dari 0,05). Selanjutnya dari hasil analisis data dengan regresi ganda diperoleh hasil sebagai berikut:

Tabel 1. Rangkuman Hasil Regresi Berganda

\begin{tabular}{lcccccc}
\hline \multicolumn{1}{c}{ Model } & Koef. & $\mathrm{t}$ & Sig. & $\mathrm{R}$ & $\mathrm{R}^{2}$ & $\mathrm{~F}$ \\
\hline Konstanta (k) & 4,594 & & & & & \\
Tingkat Pengetahuan (X1) & 0,205 & 2,206 & 0,030 & & & \\
Kualitas Layanan (X2) & 0,353 & 4,058 & 0,000 & & & \\
Tingkat Literasi Keuangan & 0,146 & 2,203 & 0,030 & & & \\
Syariah(X3) & & & & & & \\
\hline Regression(ANOVA) & & & 0,000 & 0,527 & 0,278 & 12,294 \\
\hline
\end{tabular}

\section{Pengaruh tingkat pengetahuan terhadap pengambilan keputusan masyarakat muslim menggunakan produk perbankan syariah di DIY}

Indikator yang tercakup dalam variabel Tingkat Pengetahuan adalah pengetahuan umum, pengetahuan prosedural, dan pengetahuan pembelian produk. Variabel tingkat pengetahuan termasuk dalam kategori sedang dengan frekuensi 61 responden (61\%). Hal tersebut menunjukkan bahwa responden dalam penelitian ini telah cukup memiliki pengetahuan terkait bank syariah dan produknya

Hasil penelitian ini menunjukkan bahwa terdapat pengaruh positif dari variabel tingkat pengetahuan terhadap pengambilan keputusan masyarakat muslim menggunakan produk perbankan syariah. Kesimpulan tersebut diperoleh melalui nilai t hitung sebesar 2,206 dengan signifikansi 0,030 dan nilai koefisien b1 sebesar 0,205. Oleh karena koefisien regresi mempunyai nilai positif dan memiliki signifikansi kurang dari 0,05 maka dapat disimpulkan semakin tinggi tingkat pengetahuan yang dimiliki masyarakat muslim maka akan semakin tinggi pula pengambilan keputusan menggunakan produk perbankan syariah.

Seperti yang dituliskan oleh Ahmad (2000) bahwa adanya pengetahuan akan suatu produk Bank Syariah berpengaruh terhadap keputusan nasabah menggunakan atau tidak menggunakan produk perbankan syariah. Secara umum pengetahuan merupakan segala sesuatu yang diketahui berkenaan dengan suatu hal. Seberapa tinggi tingkat pengetahuan masyarakat mengenai perbankan syariah dan produk yang mengikutinya maka akan semakin tinggi pula keputusan masyarakat untuk menggunakan produknya. Namun sebaliknya, jika pengetahuan masyarakat masih rendah 
mengenai perbankan syariah dan produknya akan menyebabkan pandangan yang kurang positif terhadap perbankan syariah.

\section{Pengaruh Kualitas Layanan terhadap Pengambilan Keputusan Masyarakat Muslim Menggunakan Produk Perbankan Syariah di DIY}

Indikator yang tercakup dalam variabel Kualitas Layanan adalah reliability, responsiveness, assurance, empathy, dan tangibles. Dilihat melalui deskripsi data penelitian dapat diketahui bahwa variabel kualitas pelayanan termasuk dalam kategori sedang dengan frekuensi 50 responden (50\%). Sedangkan sebanyak $41 \%$ berada kategori rendah. Indikasi ini bisa didasari karena masyarakat muslim sudah terlanjur menjadi nasabah bank syariah sehingga mereka bisa memberikan penilaian tersebut. Namun seharusnya ini bisa menjadi point penting yang harus diperhatikan oleh Bank dengan basis syariah bahwa kualitas pelayanan mereka masih dinilai kurang. Peningkatan kualitas pelayanan harus menjadi solusi agar para nasabah tidak lari.

Melalui hasil penelitian dapat disimpulkan bahwa terdapat pengaruh positif dari variabel kualitas pelayanan terhadap pengambilan keputusan masyarakat muslim menggunakan produk perbankan syariah. Kesimpulan tersebut dapat dibuktikan dengan nilai t hitung sebesar 4,058 dengan signifikansi 0,000 dan nilai koefisien b2 sebesar 0,353. Walaupun berdasarkan hasil penelitian menangkap bahwa Kualitas Layanan yang dimiliki Bank Syariah masih sedang dan cenderung ke rendah namun dikarenakan koefisien regresi memiliki nilai positif dan signifikansi kurang dari 0,05 maka dapat dikatakan bahwa semakin baik kualitas layanan yang diberikan bank syariah maka akan semakin tinggi pula pengambilan keputusan masyarakat muslim menggunakan produk perbankan syariah. Ini dapat menjadi pekerjaan rumah tersendiri bagi penyedia jasa keuangan syariah atau dalam hal ini Perbankan Syariah untuk terus meningkatkan kualitas layanannya agar dapat mempertahankan nasabah mereka.

Pelayanan diberikan kepada masyarakat sebagai suatu langkah perbuatan dari lembaga ataupun organisasi dalam rangka memberikan kepuasan kepada pelanggan. Pada produk Bank ada yang memerlukan pelayanan secara langsung seperti penyetoran uang tunai atau pembelian produk lainnya. Dalam transaksi tersebut dibutuhkan pelayanan berupa pemaparan tata cara dan prosedur yang harus dijelaskan oleh pegawai dari bank. Namun ada juga produk bank syariah yang tidak pemberian pelayanan langsung tatap muka oleh karyawan misalnya pelayanan yang diberikan melalui fasilitas bank seperti mesin ATM maupun e-banking. Produk yang ditawarkan oleh bank tentu memerlukan pelayanan tersendiri tergantung dengan apa yang telah ditawarkan oleh bank tersebut baik pelayanan secara langsung maupun tidak langsung. (Kasmir, 2005: 15).

Sedangkan menurut Moenir (2010) pelayanan merupakan kegiatan yang dilakukan oleh sekelompok orang dengan langkah dan pemberian perlakuan tertentu dalam hal pemenuhan dari nasabah atau konsumen suatu lembaga maupun organisasi. Tenaga karyawan Bank atau BMT selalu dituntut untuk dapat memberikan pelayanan prima kepada nasabahnya. Pelayanan prima adalah pelayanan yang sangat baik dan diharapkan dapat melebihi harapan pelanggan selama ini (Rahmayanti, 2012: 17)

\section{Pengaruh Tingkat Literasi Keuangan Syariah terhadap Pengambilan Keputusan Masyarakat Muslim Menggunakan Produk Perbankan Syariah di DIY}

Indikator yang tercakup dalam variabel Tingkat Literasi Keuangan Syariah adalah pengetahuan, kemampuan, sikap, dan kepercayaan. Menurut deskripsi data penelitian dalam pembahasan sebelumnya dapat diketahui bahwa variabel tingkat literasi keuangan syariah termasuk dalam kategori sedang dengan frekuensi 41 responden (41\%). 
Berdasarkan hasil penelitian dapat ditarik kesimpulan bahwa terdapat pengaruh positif dari variabel tingkat literasi keuangan syariah terhadap pengambilan keputusan masyarakat muslim menggunakan produk perbankan syariah. Hal ini ditunjukkan dengan nilai t hitung sebesar 2,203 dengan signifikansi 0,030 dan nilai koefisien b3 sebesar 0,146. Karena koefisien regresi mempunyai nilai positif dan signifikansi kurang dari 0,05 maka dapat disimpulkan semakin tinggi tingkat literasi keuangan syariah yang dimiliki masyarakat muslim maka akan semakin tinggi pula pengambilan keputusan masyarakat muslim menggunakan produk perbankan syariah.

Hal ini tidak sejalan dengan penelitian yang dilakukan oleh Aksanul Khosasi dalam skripsinya yang berjudul "Pengaruh Literasi Keuangan Syariah dan Pemasaran terhadap Keputusan Nasabah Melakukan Pembiyaan Mikro di Bank Syariah Bukopin Sidoarjo" yang menunjukkan bahwa variabel literasi keuangan syariah tidak berpengaruh secara signifikan terhadap keputusan nasabah melakukan pembiayaan mikro di Bank Syariah Bukopin Sidoarjo.

Menurut Agustianto (2010) menerangkan bahwa literasi keuangan syariah dapat menghasilkan banyak benefit besar teruntuk jasa keuangan syariah pada khususnya dan jasa keuangan pada umumnya. Kedua belah pihak yaitu masyarakat atau dalam hal ini nasabah dan lembaga jasa keuangan syariah memiliki hubungan yang saling membutuhkan satu sama lain sehingga semakin tinggi tingkat literasi keuangan syariah masyarakat, maka semakin banyak masyarakat yang akan memanfaatkan produk dan jasa dari lembaga keuangan syariah. Kemungkinan profit yang akan diperoleh lembaga jasa keuangan syariah juga otomatis menjadi semakin besar dan lebar peluangnya.

Selain hal tersebut, semakin tinggi tingkat literasi keuangan syariah masyarakat dapat mendorong pertumbuhan industri lembaga keuangan syariah untuk terus memperbaharui dan menciptakan produk baru yang lebih inovatif, kreatif, dan merakyat tentunya, selaras dengan keadaan masyarakat yang ada di Indonesia. Begitu pun juga dengan masyarakat agar dapat terhindar dari investasi bodong. Selain itu untuk menjadi tolak ukur majunya perekonomian suatu negara adalah tingginya tingkat melek keuangan warga negaranya. Peran dari Pemerintah serta tokoh-tokoh terkait sangat dibutuhkan dalam pemberian sosialisasi ke setiap wilayah yang ada di Indonesia.

\section{SIMPULAN}

Berdasarkan data yang telah diperoleh dari penelitian dan hasil analisis yang telah dilakukan, maka kesimpulan yang dapat dikemukakan oleh penulis dalam penelitian ini adalah terdapat pengaruh positif tingkat pengetahuan terhadap pengambilan keputusan masyarakat muslim menggunakan Produk Perbankan Syariah di DIY, terdapat pengaruh positif kualitas layanan terhadap pengambilan keputusan masyarakat muslim menggunakan Produk Perbankan Syariah di DIY, terdapat pengaruh positif tingkat literasi keuangan syariah terhadap pengambilan keputusan masyarakat muslim menggunakan Produk Perbankan Syariah di DIY, serta terdapat pengaruh positif tingkat pengetahuan, kualitas layanan, dan tingkat literasi keuangan syariah terhadap pengambilan keputusan masyarakat muslim menggunakan Produk Perbankan Syariah di DIY. Selain itu hasil pengujian regresi ganda menunjukkan bahwa tingkat pengetahuan, kualitas layanan, dan tingkat literasi keuangan syariah mempengaruhi 27,8\% pengambilan keputusan masyarakat muslim menggunakan produk perbankan syariah di DIY.

Berdasarkan penelitian tersebut, dikemukakan beberapa saran. Bagi pelaku usaha Perbankan Syariah seharusnya dapat melakukan sosialisasi secara menyeluruh dan jelas kepada masyarakat terkait produk yang ditawarkan serta prosedur penggunaannya atau dalam bahasa yang lebih sederhana yaitu perlu memberikan iklan yang menarik. Iklan dapat dipublikasikan melalui media 
cetak, media elektronik, serta web perusahaan. Hal tersebut perlu dilakukan agar mempermudah calon nasabah dalam mendapatkan informasi tanpa harus pergi mendatangi kantor cabang Bank Syariah.

Bagi Pemerintah, dalam rangka mewujudkan masyarakat yang melek keuangan, seharusnya mendukung penuh kegiatan terkait pemberian literasi keuangan syariah kepada masyarakat. Selain Pemerintah, pihak Perbankan Syariah serta masyarakat dengan tingkat literasi keuangan syariah tinggi seharusnya dapat bekerjasama dalam meningkatkan kesadaran masyarakat terkait melek keuangan agar terhindar dari jerat rentenir serta investasi bodong yang marak terjadi. Bagi Karyawan Bank Syariah harus memiliki sikap ramah, ulet, teliti dan penguasaan pengetahuan terkait produknya. Ruang tunggu yang nyaman dan tempat parkit yang luas juga menjadi nilai tambah tersendiri dalam memanjakan nasabah Bank Syariah Bagi peneliti selanjutnya diharapkan dapat menggunakan variabel lain dalam meneliti faktor apa saja yang dapat mempengaruhi keputusan masyarakat muslim dalam menggunakan produk Perbankan Syariah.

\section{DAFTAR PUSTAKA}

Agustianto. (2014). Membangun Literasi Keuangan Syariah. Diakses online pada laman: http://www.agustiantocntre.com/?p=1674 pada tanggal 7 Agustus 2018.

Ahmad, A. (2000). Asas-Asas Hukum Muamalat. Yogyakarta: UII Pers.

Bank Indonesia. (2007). Panduan Investasi Perbankan Syariah. Direktorat Perbankan Syariah.

Bank Indonesia. (2008). Undang-Undang RI No. 21 Tahun 2008 tentang Perbankan Syariah. Diakses online pada laman: www.bi.go.id pada tanggal 29 Juli 2018.

Kasmir. (2002). Bank dan Lembaga Keuangan Lainnya. Jakarta: PT Rajagrafindo Persada.

Lemeshow, S., Hosmer, D.W., Klar, J. (1990). Adequacy of Sample Size in Health Studies. England: John Wiley and Sons Ltd.

Lupiyoadi, Rambat \& Hamdani, A. (2008). Manajemen Pemasaran Jasa. Jakarta: Salemba Empat.

Muhson, Ali. (2017). Pedoman Praktikum Analisis Statistik (Edisi 2). Yogyakarta: Fakultas Ekonomi Universitas Negeri Yogyakarta.

Otoritas Jasa Keuangan. (2018). Statistik Perbankan Syariah. Jakarta: Departemen Perizinan dan Informasi Perbankan.

Rahmayanti, N. (2012). Manajemen Pelayanan Prima. Yogyakarta: Graha Ilmu.

Remund, D.L. (2010). "Financial Literacy Explicated: The Case for a Clearer Definition in an Increasingly Complex Economy". The Journal of Consumer Affairs (Vol. 44(2)).

Sugiyono. (2015). Metode Penelitian Administrasi dilengkapi dengan Metode R EDD. Bandung: Alfabeta.

Undang-Undang No 08 Tahun 1998 tentang Perbankan Syariah.

Undang-Undang No 21 Tahun 2008 tentang Perbankan Syariah. 